\title{
UPAYA MENINGKATKAN KETERAMPILAN PROSES SAINS DAN MENGURANGI MISKONSEPSI MELALUI PENERAPAN E-MODULE BERBASIS PROBLEM-BASED LEARNING KELAS X MIA 2 SMA BATIK 1 SURAKARTA
}

\section{THE EFFORT TO INCREACING SCIENTIFIC PROCESS SKILLS AND REDUCING MISCONCEPTION THROUGH THE APPLICATION OF E-MODULE BASED ON PROBLEM-BASED LEARNING IN THE X MIA 2 GRADERS OF SMA BATIK 1 SURAKARTA}

\author{
HENNY PURNAMA WATI ${ }^{1 *}$, PUGUH KARYANTO, SRI DWIASTUTI, DYNNA SRI \\ WULANDARI ${ }^{2}$ \\ ${ }^{1}$ Program Studi Pendidikan Biologi \\ Fakultas Keguruan dan Ilmu Pendidikan \\ Universitas Sebelas Maret \\ Jl. Ir. Sutami 36 A, Surakarta, 57126, Indonesia \\ ${ }^{2}$ SMA Batik 1 Surakarta \\ *Corresponding Author: hay_niez@yahoo.co.id
}

Manuscript received : 11 Januari 2016 Revision accepted: 22 Maret 2016

\begin{abstract}
This research aimed to improve the scientific process skills and reduce misconception through the application of E-Module based on Problem-Based Learning in the X MIA 2 graders of SMA Batik 1 Surakarta. This research was a Classroom Action Research consisting of 2 cycles. Each cycle consisted of four stages: planning, acting, observing, and reflecting. The subject of research was the X MIA 2 graders of SMA Batik 1 Surakarta consisting of 42 students. Techniques of collecting data used were multiple choice test and observation to measured scientific process skills, open-ended reasoning of Two-Tier Diagnostic Test to measure misconseption, and interveiw as the proponent data related learning process. The data were analyzed using descriptive qualitative technique consist of three component: data reduction, data presentation, and taking the conclusion. Data validation was carried out using triangulation method. Target of research was $20 \%$ to increased scientific process skills and $20 \%$ to reduced misconseption at the end of the cycle. The result of research showed that the scientific process skills to able increased through the application of E-Module based on Problem-Based Learning in all aspects: observing of 29.83\%, categorizing of $11.73 \%$, predicting of $37.33 \%$, interpreting of $30.71 \%$, measuring of $35.66 \%$, communicating of $32.39 \%$, designing experiment of $30.04 \%$, experimenting of $21.82 \%$, asking question of $23.42 \%$, hypothesizing of $36.73 \%$, and applying concept of $42.58 \%$. On the other side, the result of research also showed that there was a decreased misconception in ecological concept: population of $51.31 \%$, community of $43.73 \%$, ecosystem of $39.36 \%$, and science, environment, technology and community (salingtemas) ecology of $54.33 \%$. The conclusion of this research described that there was an increasing scientific process skills of $28.96 \%$ and reducing misconception of $47.18 \%$ by used the application of E-Module based on Problem-Based Learning.
\end{abstract}

Keywords : Scientific Process Skills, Misconception, E-Module based on Problem Based Learning.

\section{PENDAHULUAN}

Belajar adalah proses perubahan tingkah laku seseorang akibat pengalaman dan latihan terhadap cara berinteraksi dengan keadaan (Gagne, 1984). Perubahan tingkah laku tidak hanya dilihat dari perubahan sifat fisik tetapi perubahan pada kemampuan meliputi pengetahuan, sikap dan keterampilan individu dalam jangka waktu yang relatif lama (Siregar, 2010).

Pembelajaran biologi di kelas X MIA 2 SMA Batik 1 Surakarta tidak diimbangi dengan sikap aktif dari peserta didik. Peserta didik pasif dan kurang berani menyampaikan pendapat ataupun bertanya kepada guru. Peserta didik kurang terampil dalam pengelompokkan masalah, berkomunikasi yang benar, menyusun hipotesis dengan tepat, dan menarik kesimpulan sesuai topik permasalahan. Pemanfaatan fasilitas belajar seperti penggunaan laboratorium biologi kurang maksimal yang berdampak pada pengetahuan dan keterampilan peserta didik untuk menggunakan alat bahan. Peserta didik dalam menjawab pertanyaan guru sering membaca literature yang terbatas pada satu buku dan tidak mengandalkan gagasan yang dimiliki sehingga pengembangan aspek kognitif, afektif, dan psikomotor peserta didik belum optimal. Proses pembelajaran yang berlangsung belum 
mengakomodasi peserta didik untuk mengembangkan keterampilan proses sains.

Keterampilan proses sains dibutuhkan dalam pembelajaran abad 21 sehingga harus dilatih dan dikembangkan dalam proses pembelajaran (Turiman, Oman, Daud \& Osman, 2012). Keterampilan proses sains merupakan keterampilan yang melibatkan keterampilan intelektual dan fisik untuk memecahkan masalah dan merumuskan hasil secara ilmiah sebagai dasar pengembangan diri dan sosial (Ongowo, 2013). Keterampilan proses sains yang dikembangkan dalam pembelajaran meliputi keterampilan dasar dan terintegrasi yang secara keseluruhan mencakup 11 aspek yaitu mengamati, mengelompokkan, memprediksi, menafsirkan, mengukur, berkomunikasi, merancang percobaan, bereksperimen, mengajukan pertanyaan, berhipotesis, dan menerapkan konsep (Rustaman, 2005 dan Dimyanti \& Mudjiono, 1999).

Hasil observasi lanjutan terhadap aspek keterampilan proses sains peserta didik menggunakan lembar observasi dan didukung dengan soal tes. Hasil observasi menunjukkan aspek mengamati sebesar $36,90 \%$, mengelompokkan $27,98 \%$, memprediksi $2,38 \%$, menafsirkan 2,38\%, mengukur $14,29 \%$, berkomunikasi $9,52 \%$, mengajukan pertanyaan $21,43 \%$, berhipotesis $2,98 \%$, merencanakan percobaan $8,93 \%$, bereksperimen $20,83 \%$, dan menerapkan konsep 5,95\%. Hasil capaian menunjukkan bahwa setiap aspek keterampilan proses sains tergolong rendah, sehingga perlu dikembangkan dan ditingkatkan. Keterampilan proses sains dapat dikembangkan melalui pembelajaran yang menciptakan lingkungan belajar yang mampu menyajikan permasalahan untuk memperoleh pengetahuan dan pengalaman baru peserta didik (Amir, 2009). Melalui pembelajaran berbasis masalah peserta didik dapat mengembangkan keterampilan mengajukan dan menyelesaikan masalah yang rumit, mengemukakan pendapat, meningkatkan kerjasama, meningkatkan keaktifan, serta mengembangkan kemampuan pola analisis dan proses nalar sehingga dapat meningkatkan keterampilan proses sains yang masih rendah (Suprijono, 2009).

Permasalahan yang muncul berdasarkan hasil observasi terkait proses yaitu keterampilan proses sains peserta didik setiap aspek tergolong rendah. Berdasarkan observasi lanjutan terkait hasil belajar kognitif ditemukan permasalahan lain yaitu muncul miskonsepsi pada jawaban peserta didik terhadap soal konsep Ekologi yang diujikan. Soal mengenai konsep Ekologi yang diujikan terdiri dari empat konsep penting, yaitu konsep populasi, komunitas, ekosistem, dan Ekologi salingtemas.

Hasil observasi menunjukkan bahwa rata-rata capaian skor miskonsepsi peserta didik tiap konsep penting pada materi Ekologi masih tergolong tinggi.
Peserta didik mengalami miskonsepsi sebesar 72,42\% pada konsep populasi, konsep komunitas terdapat miskonsepsi sebesar 55,95\%, konsep ekosistem sebesar $57,19 \%$, dan miskonsepsi paling tinggi yang dialami peserta didik yaitu pada konsep Ekologi saling temas sebesar 87,20\% (Observasi peneliti, Februari 2015).

Miskonsepsi muncul akibat penjelasan konsep yang tidak akurat, penggunaan dan penerapan konsep yang salah, pemaknaan konsep yang berbeda, kekacauan konsep dan hubungan hierarki konsep yang tidak benar (Suparno, 2005). Miskonsepsi dapat terjadi ketika lingkungan belajar seperti referensi yang dirujuk, pebelajar sebaya, dan guru yang berperan dalam penyebaran miskonsepsi (Tekkaya, 2002). Merujuk pada faktor penyebab miskonsepsi, upaya yang dapat dilakukan untuk mengurangi miskonsepsi adalah pelatihan pemecahan masalah dengan pendekatan kontekstual (Tekkaya, 2002).

Permasalahan penting yang dirumuskan berdasarkan hasil observasi yaitu rendahnya keterampilan proses sains dan muncul banyak miskonsepsi terkait materi Ekologi. Bordner (1986) lemahnya keterampilan proses sains dan miskonsepsi peserta didik dapat diatasi dengan penerapan pembelajaran bermakna (Suwarto, 2013). Model pembelajaran yang menerapkan pembelajaran bermakna adalah model Problem-Based Learning.

Problem-Based Learning merupakan model pembelajaran yang menghadapkan peserta didik pada masalah autentik sehingga peserta didik dapat menyusun pengetahuan sendiri, menumbuhkembangkan keterampilan lebih tinggi, memandirikan peserta didik, dan meningkatkan kepercayaan diri sendiri (Arends, 2008). Masalah dalam Problem-Based Learning menekankan pada masalah nyata yang tidak terstruktur (ill-structured) dan bersifat terbuka sebagai konteks bagi peserta didik untuk mengembangkan keterampilan memecahkan masalah dan membangun pengetahuan baru (Hosnan, 2014).

Problem-Based Learning diperlukan untuk mengurangi miskonsepsi dan meningkatkan keterampilan proses sains peserta didik. Miskonsepsi peserta didik dapat diminimalisir melalui pembelajaran bermakna yang menyajikan permasalahan untuk memperoleh pengetahuan dan pengalaman baru peserta didik (Amir, 2009). Karakteristik ProblemBased Learning memiliki potensi dapat meningkatkan keterampilan proses sains dan mampu mengurangi miskonsepsi peserta didik pada materi Ekologi. Problem-Based Learning memiliki kelemahan dari segi pelaksanaan yaitu membutuhkan waktu yang lama dalam pemecahan masalah, sehingga efektivitas dan efisiensi penerapan Problem-Based Learning perlu 
didukung penggunaan sumber dan media belajar yang efektif yaitu E-Module.

E-Module merupakan modul berbasis teknologi informasi yang bersifat interaktif memudahkan dalam penyelidikan, menampilkan gambar, audio, video, animasi, dan dilengkapi tes evaluasi sebagai umpan balik dari pembelajaran (Suarsana \& Mahayukti, 2013). E-Module berbasis Problem-Based Learning didesain sebagai sumber dan media belajar yang merujuk pada karakteristik dan sintaks Problem-Based Learning (Masek \& Yamin, 2010; Martiyono, 2012). Karakteristik E-Module yang terdapat pada tahapan Problem-Based Learning terdiri dari petunjuk pemecahan masalah, pengamatan video permasalahan, merumuskan masalah, merumuskan hipotesis yang dilengkapi informasi fisiologi dan ekologi hasil riset, menyajikan data, presentasi hasil analisis data, menyajikan kesimpulan, rangkuman belajar, evaluasi proses, dan evaluasi hasil (Fakhrudin, 2014).

Keunggulan E-Module mempermudah peserta didik mengenali materi pelajaran yang berpotensi memberikan pemahaman konsep yang lebih baik dan menuntun peserta didik untuk memecahkan permasalahan secara mandiri sehingga dapat melatih dan menumbuhkan keterampilan berpikir tingkat tinggi yang berdampak pada pemahaman konsep peserta didik (Suarsana \& Mahayukti, 2013). Tampilan objek berupa gambar, audio, animasi, dan materi ajar pada E-Module mampu mengakomodasi peningkatan keterampilan proses sains peserta didik yaitu keterampilan observasi, komunikasi, mengajukan pertanyaan, menerapkan konsep, membuat hipotesis dan memprediksi fenomena yang disajikan dalam $E$ Module.

Tujuan penelitian ini adalah meningkatkan keterampilan proses sains dan mengurangi miskonsepsi peserta didik kelas X MIA 2 SMA Batik 1 Surakarta melalui penerapan E-Module berbasis Problem-Based Learning.

\section{METODE PENELITIAN}

Penelitian ini merupakan Penelitian Tindakan Kelas yang dilaksanakan di kelas X MIA 2 SMA Batik 1 Surakarta. Data yang dikumpulkan berupa data utama mengenai miskonsepsi dan keterampilan proses sains peserta didik serta data penunjang meliputi keterlaksanaan sintaks. Sumber data diperoleh dari informasi catatan observasi peneliti di lapangan, hasil wawancara guru dan peserta didik serta dokumentasi.

Pengumpulan data dilakukan dengan teknik tes dan teknik non tes. Teknik tes menggunakan tes keterampilan proses sains berupa soal pilihan ganda dan two-tier diagnostic test berupa soal pilihan ganda disertai alasan terbuka untuk mengetahui miskonsepsi peserta didik. Teknik non tes berupa observasi, wawancara, dan dokumentasi. Validasi data yang digunakan dalam penelitian adalah teknik triangulasi. Sugiyono (2012), teknik triangulasi merupakan teknik pengumpulan data yang menggabungkan berbagai teknik pengumpulan data dan sumber data yang telah ada untuk menguji kebenaran datanya. Analisis data yang digunakan dalam penelitian adalah teknik analisis deskriptif kualitatif. Teknik analisis data yang digunakan mengacu pada model analisis Miles dan Huberman (1984) yang dilakukan secara interaktif melalui 3 komponen, yaitu reduksi data, penyajian data, dan penarikan kesimpulan (Sugiyono, 2012). Prosedur penelitian mengacu pada model spiral Kemmis dan Taggart (1988) meliputi empat tahap yaitu perencanaan, pelaksanaan, observasi, dan refleksi (Wiriaatmadja, 2005). Penelitian tindakan kelas dilaksanakan secara bersiklus dan siklus dapat dihentikan ketika keseluruhan aspek keterampilan proses sains mengalami peningkatan $20 \%$ setiap aspek di akhir siklus disesuaikan dengan kondisi dan keadaan peserta didik di kelas (Kale, 2013) serta miskonsepsi pada konsep Ekologi mengalami penurunan $20 \%$ di akhir siklus berdasarkan pertimbangan peneliti dan guru sesuai kondisi peserta didik serta keadaan kelas (Suwarto, 2013).

\section{HASIL DAN PEMBAHASAN}

Pembelajaran dengan menerapkan E-Module berbasis Problem-Based Learning di kelas X MIA 2 SMA Batik 1 Surakarta dilakukan melalui kegiatan yang mampu merangsang keterampilan proses sains dengan menyajikan fenomena permasalahan sesuai kenyataan di lapangan.

Hasil penelitian di kelas X MIA 2 SMA Batik 1 Surakarta menunjukkan setiap aspek keterampilan proses sains peserta didik meningkat dan miskonsepsi peserta didik pada materi Ekologi berkurang melalui penerapan E-Module berbasis Problem-Based Learning.

\section{Keterampilan Proses Sains}

Keterampilan proses sains mengalami peningkatan pada setiap aspek yaitu mengamati, mengelompokkan, memprediksi, menafsirkan, mengukur, berkomunikasi, merancang percobaan, bereksperimen, mengajukan pertanyaan, berhipotesis, dan menerapkan konsep. Peningkatan setiap aspek keterampilan proses sains menunjukkan kenaikan persentase yang berbeda dari tahap pratindakan hingga Siklus II. Peningkatan setiap aspek keterampilan proses sains dari pratindakan hingga Siklus II ditunjukkan pada Gambar 1. 


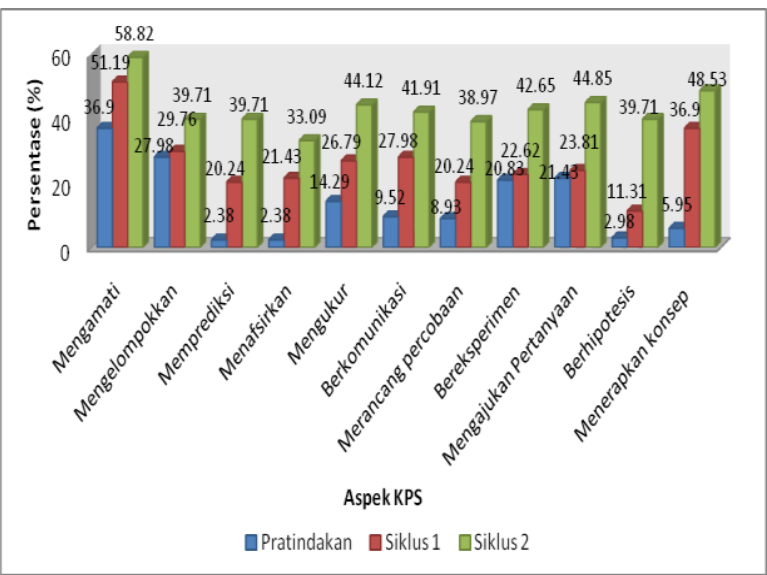

Gambar 1. Perbandingan Capaian Aspek Keterampilan Proses Sains.

Gambar 1 bahwa seluruh aspek keterampilan proses sains mengalami peningkatan pada setiap siklus. Peningkatan untuk aspek mengamati yaitu dari $36,90 \%$ menjadi $58,82 \%$ adalah $21,92 \%$, aspek mengelompokkan dari $27,98 \%$ menjadi $39,71 \%$ adalah $11,73 \%$, aspek memprediksi dari $2,38 \%$ menjadi $39,71 \%$ adalah $37,33 \%$, aspek menafsirkan dari $2,38 \%$ menjadi $33,09 \%$ adalah $30,71 \%$, aspek mengukur dari $14,29 \%$ menjadi $44,12 \%$ adalah $29,83 \%$, aspek berkomunikasi dari $9,52 \%$ menjadi $41,91 \%$ adalah $32,39 \%$, aspek merancang percobaan dari $8,93 \%$ menjadi $38,97 \%$ adalah $30,04 \%$, aspek bereksperimen dari $20,83 \%$ menjadi $42,65 \%$ adalah $21,82 \%$, aspek mengajukan pertanyaan dari $21,43 \%$ menjadi $44,85 \%$ adalah $23,42 \%$, aspek berhipotesis dari $2,98 \%$ menjadi $39,71 \%$ adalah $36,73 \%$, dan aspek menerapkan konsep dari 5,95\% menjadi 48,53\% adalah $42,58 \%$.

Aspek keterampilan proses sains yang harus dikembangkan peserta didik dalam pembelajaran adalah keterampilan proses sains dasar dan keterampilan proses sains terintegrasi (Ongowo \& Indoshi, 2013). Pengkombinasian keterampilan proses dasar dan terintegrasi mampu merangsang peserta didik belajar mengembangkan pengetahuan dan keterampilan untuk menemukan sendiri penyelesaian masalah melalui suatu eksperimen (Delismar, Ashyar, \& Hariyadi, 2013). Menurut Suprijono (2009) melalui pembelajaran berbasis masalah peserta didik dapat lebih mudah mencari penyelesaian masalah dapat mengembangkan keterampilan mengajukan dan menyelesaikan masalah yang rumit, mengemukakan pendapat, serta mengembangkan kemampuan menganalisis dan menalar proses permasalahan.

Berdasarkan hasil penelitian, peningkatan keseluruhan aspek keterampilan proses sains dari pratindakan hingga Siklus II telah sesuai dengan target penelitian yaitu 20\%, kecuali aspek mengelompokkan. Ketidaktercapaian aspek keterampilan proses sains dikarenakan peserta didik tidak berpikir kreatif dalam proses pemecahan masalah sehingga berdampak pada kemampuan berpikir dan keterampilan peserta didik (Aktamis \& Ergin, 2008).

Penerapan media pembelajaran sangat diperlukan dalam pembelajaran untuk menunjang keberhasilan belajar peserta didik (Smaldino \& Lowther, 2008). Salah satu media pembelajaran yang berpotensi meningkatkan keterampilan proses sains peserta didik adalah modul berbasis teknologi (E-Module). Penggunaan modul yang berorientasi pemecahan masalah dapat menuntun peserta didik untuk memecahkan permasalahan secara mandiri sehingga melatih dan menumbuhkan keterampilan berpikir tingkat tinggi peserta didik yang berdampak pada pemahaman konsep peserta didik (Suarsana \& Mahayukti, 2013). Ausubel (1968) menyatakan keterampilan proses sains memiliki langkah penting untuk membangun pemahaman konsep, teori, dan prosedur ilmiah untuk memecahkan permasalahan (Ango, 2002). Kemampuan memecahkan masalah memerlukan pemahaman yang benar dan kuat pada konsep sehingga tidak menimbulkan miskonsepsi.

\section{Miskonsepsi}

Berdasarkan hasil penelitian menunjukkan bahwa peserta didik banyak mengalami miskonsepsi pada materi Ekologi. Penerapan E-Module berbasis Problem-Based Learning berpotensi mampu mengurangi miskonsepsi peserta didik pada materi Ekologi. Materi Ekologi mencakup empat konsep penting yaitu konsep populasi, komunitas, ekosistem, dan Ekologi salingtemas. Capaian hasil miskonsepsi pada setiap konsep penting Ekologi menunjukkan terjadi pengurangan persentase yang berbeda dari tahap pratindakan hingga Siklus II yang ditunjukkan pada Gambar 2.

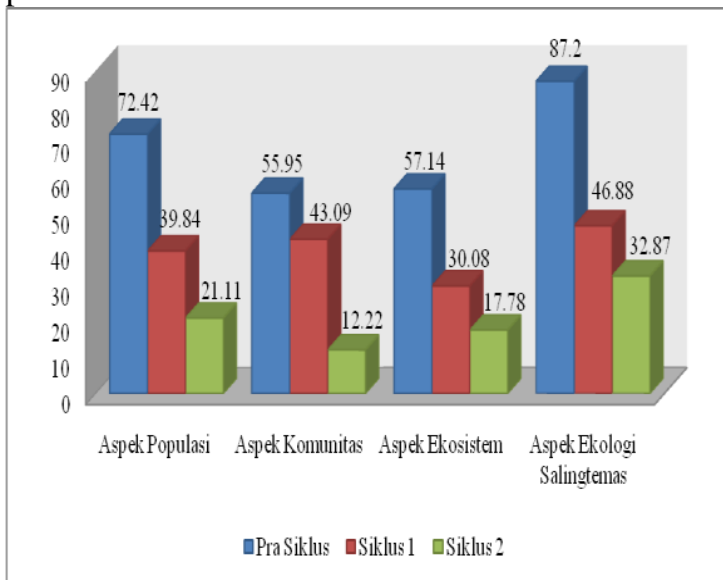

Gambar 2. Perbandingan Miskonsepsi Setiap Konsep Penting Ekologi.

Gambar 2 menunjukkan terjadi penurunan angka miskonsepsi pada keseluruhan konsep penting Ekologi dari pratindakan hingga Siklus II. Penurunan angka 
miskonsepsi untuk setiap konsep penting Ekologi yaitu konsep populasi dari $72,42 \%$ menjadi $21,11 \%$ adalah $51,31 \%$, konsep komunitas dari $55,95 \%$ menjadi $12,22 \%$ adalah $43,73 \%$, konsep ekosistem dari 57,14\% menjadi $17,78 \%$ adalah $39,36 \%$, dan konsep Ekologi salingtemas dari $87,20 \%$ menjadi $32,87 \%$ adalah $54,33 \%$. Penurunan angka miskonsepsi berdampak pada berkurangnya miskonsepsi peserta didik terhadap konsep penting Ekologi.

Pengurangan miskonsepsi dapat diidentifikasi melalui two-tier diagnostic test berupa tes pilihan ganda disertai alasan terbuka (Khrisnan \& Howe, 1994). Keunggulan yang dimiliki oleh tes pilihan ganda yang disertai alasan terbuka dalam mendeteksi miskonsepsi peserta didik yaitu guru dapat menentukan tipe kesalahan peserta didik dalam menjawab pertanyaan berdasarkan konsep yang diketahuinya sehingga dapat terhindar dari resiko peserta didik menebak jawaban (Mustaqim, Zulfiani, \& Herlanti, 2014).

Penerapan E-Module berbasis Problem-Based Learning dalam pembelajaran memfasilitasi peserta didik untuk menyelesaikan masalah sesuai informasi atau konsep yang dipaparkan dalam E-Module. Melalui penerapan E-Module berbasis Problem-Based Learning, peserta didik mampu mengembangkan kemampuan intelektual untuk membangun pengetahuan sendiri melalui pengalaman belajar dan interaksi sosial dengan lingkungan sehingga dapat menciptakan lingkungan belajar yang bermakna (Sugiyanto, 2009). Pengkonstruksian pengetahuan dilakukan pada penekanan perubahan persepsi dan pemahaman peserta didik terhadap materi pembelajaran kearah pemahaman yang benar (Anitah, 2009). Peserta didik juga dituntut belajar menemukan pemahaman sendiri dan mampu menghubungkan pengetahuan baru dengan pengetahuan lama yang dimiliki peserta didik sebagai bekal untuk membangun makna baru yang benar (Arends, 2008).

Berdasarkan hasil penelitian, pengurangan miskonsepsi peserta didik pada konsep Ekologi dari pratindakan hingga Siklus II telah sesuai dengan target penelitian yaitu $20 \%$.

Pembelajaran dengan menerapkan E-Module berbasis Problem-Based Learning memiliki permasalahan yang dekat dengan kehidupan peserta didik yaitu fenomena terkait penurunan produksi padi oleh hama tikus yang berasal dari demo video. Menurut Rusmono (2012), pembelajaran tersebut dapat membuat peserta didik lebih tertarik untuk mempelajari dan berlatih bersikap tanggungjawab secara mandiri dalam membangun konsep melalui proses pembelajaran (Rusmono, 2012).

Hasil penelitian secara keseluruhan menunjukkan miskonsepsi peserta didk pada materi Ekologi berkurang dari pratindakan hingga Siklus II sesuai target penelitian melalui penerapan E-Module berbasis Problem-Based Learning. Hasil tersebut sesuai dengan jurnal Parmin dan Peniati (2012) yang menyatakan bahwa pembelajaran dengan menerapkan media berupa modul yang dikembangkan melalui hasil penelitian mampu mengubah konsepsi peserta didik menuju konsep ilmiah. Penerapan modul berteknologi yang berbasis masalah mampu mengubah miskonsepsi peserta didik melalui proses pengkonstruksian konsep yang didasarkan atas pengetahuan awal dan pengetahuan baru peserta didik sehingga peserta didik dapat memahami konsep baru yang diperoleh dari hasil belajarnya secara benar.

\section{KESIMPULAN}

Berdasarkan hasil penelitian dan pembahasan dapat disimpulkan bahwa:

1. Ada peningkatan keterampilan proses sains melalui penerapan E-Module berbasis ProblemBased Learning sebesar 28,96\% di kelas X MIA 2 SMA Batik 1 Surakarta.

2. Ada pengurangan miskonsepsi melalui penerapan E-Module berbasis Problem-Based Learning sebesar 47,18\% di kelas X MIA 2 SMA Batik 1 Surakarta.

\section{DAFTAR PUSTAKA}

Aktamis, H., \& Ergin, O. (2008). The Effect of Scientific Process Skills Education on Student's Scientific Creativity, Science Attitudes and Academic Achievements. Article of Asia-Pasific Forum on Science Learning and Teaching , 9 (1), 1-21.

Amir, M. (2009). Inovasi Pendidikan Melalui Problem Based Learning. Jakarta: Kencana Predana Media.

Ango, M. L. (2002). Mastery of Science Process Skills and Their Effective Use in the Teaching of Science: An Educology of Science Education in the Nigerian Context. International Journal of Educology, 16 (1).

Anitah, S. (2009). Teknologi Pembelajaran. Surakarta: UNS Press.

Arends, R.I. (2008). Learning to Teach: Belajar untuk Mengajar. Yogyakarta: Pustaka Pelajar.

Ausubel, D. P. (1968). Educational Psychology. A Cognitive View. New York: Holt Rinehart and Winston.

Delismar, Ahsyar, R., \& Hariyadi, B. (2013). Peningkatan Kreativitas dan Keterampilan Proses Sains Siswa Melalui Penerapan Model Group Investigation. Jurnal Edu-Sains , 1 (2), 25-32.

Dimyati, \& Mudjiono. (1999). Belajar dan Pembelajaran. Jakarta: PT. Rineka Cipta.

Fakhrudin, I. A. (2014). Pengembangan E-Modul Ekosistem Berbasis Problem Based Learning pada Sub Pokok Bahasan Aliran Energi untuk Sekolah Menengah Atas Tahun Pelajaran 2014/1015. Surakarta: UNS Press. 
BIO-PEDAGOGI 5(1): 32 - 37, April 2016

Gagne, R. M. (1984). Learning Outcomes and Their Effect Useful Categories of Human Performance. Journal of American Psychologist, 39 (4), 377-385.

Hosnan, M. (2014). Pendekatan Saintifik dan Kontekstual dalam Pembelajaran Abad 21. Bogor: Ghalia Indonesia.

Kemmis, \& Taggart. (1988). The Action Research Planner 3rd ed. Victoria: Deaklin University.

Krishnan, S. R., \& Howe, A. C. (1994). The Mole Concept: Developing an Instrument to Assess Conceptual Understanding. Journal of Chemical Education , 71 (8), 653-655.

Masek, A., \& Yamin, S. (2010). Problem Based Learning: A Collection from The Literature. Journal of Asian Social Science, 6 (8), 148-158.

Miles, \& Huberman. (1984). Data Kualitatif. Jakarta: UI Press.

Mustaqim, T. A., Zulfiani, \& Herlanti, Y. (2014). Identifikasi Miskonsepsi Siswa dengan Menggunakan Metode Certainty of Response Index (CRI) pada Konsep Fotosintesis dan Respirasi Tumbuhan. Edusains , 6 (2), 147-152.

Ongowo, R. O., \& Indoshi, F. C. (2013). Science Process Skills in The Kenya Certificate of Secondary Education Biology Practical Examinations. Journal of Creative Education , 4 (11), 713-717.

Parmin \& Peniati, E. (2012). Pengembangan Modul Mata Kuliah Strategi Belajar Mengajar IPA Berbasis Hasil Penelitian Pembelajaran. Jurnal Pendidikan IPA Indonesia. 1(1), 8-15.

Rusmono. (2012). Strategi Pembelajaran dengan Problem Based Learning Itu Perlu: untuk Meningkatkan Profesionalitas Guru. Bogor: Ghalia Indonesia.

Rustaman, N. (2005). Strategi Belajar Mengajar Biologi. Malang: UM Press.

Siregar, E. (2010). Teori Belajar dan Pembelajaran. Bogor: Ghalia Indonesia.

Smaldino, S.E., \& Lowther, D.L. (2008). Intructional Technology and Media for Learning. New Yersey: Pearson Prentice Hall.

Suarsana, I. M., \& Mahayukti, G. (2013). Pengembangan EModul Berorientasi Pemecahan Masalah untuk Meningkatkan Keterampilan Berpikir Kritis Mahasiswa. Jurnal Pendidikan Indonesia , 2 (2).

Sugiyanto. (2009). Model-Model Pembelajaran Inovatif. Surakarta: UNS Press.

Sugiyono. (2012). Model Penelitian Pendidikan Pendekatan Kuantitatif, Kualitatif, dan $R \& D$. Bandung: Alfabeta.

Suparno. (2005). Miskonsepsi dan Perubahan Konsep Pendidikan Fisika. Jakarta: PT.Grasindo.

Suprijono, A. (2009). Teori Pembelajaran Kooperatif dan Aplikasi PAIKEM. Yogyakarta: Pustaka Belajar.

Suwarto. (2013). Belajar Tuntas, Miskonsepsi dan Kesulitan Belajar. Junal Pendidikan , 22 (1), 85-96.

Tekkaya, C. (2002). Misconceptions as Barrier to Understanding Biology. Journal of Education , 23, 259266.

Turiman, P., Oman, J., Daud, A. M., \& Osman, K. (2012). Fostering the 21st Century Skills Through Scientific Literacy and Science Process Skills. Procedia-Social and Behavioral Sciences (59).

Wiriaatmaja, R. (2005). Metode Penelitian Tindakan Kelas. Bandung: PT. Remaja Rosdakarya. 